\title{
Lingering Impacts of Hurricane Hugo on Rhizophora mangle (Red Mangrove) Population Genetics on St. John, USVI
}

\author{
Paul. A. X. Bologna ${ }^{1, *,+} \mathbb{0}$, James J. Campanella ${ }^{2,+}{ }^{,}$Dena J. Restaino ${ }^{2,3}$, Zachary A. Fetske ${ }^{2}$, \\ Matthew Lourenco ${ }^{2}$ and John V. Smalley ${ }^{4}$ \\ 1 Marine Biology and Coastal Sciences, Montclair State University, 1 Normal Ave., Montclair, NJ 07043, USA \\ 2 Department of Biology, Montclair State University, 1 Normal Ave., Montclair, NJ 07043, USA; \\ campanellaj@montclair.edu (J.J.C.); drestaino@ccm.edu (D.J.R.); fetskez1@mail.montclair.edu (Z.A.F.); \\ mathew.lourenco@gmail.com (M.L.) \\ 3 Department of Biology and Chemistry, County College of Morris, 214 Center Grove Rd, \\ Randolph, NJ 07869, USA \\ 4 Department of Biology and Horticulture, Bergen Community College, Paramus, NJ 07652, USA; \\ jsmalley@bergen.edu \\ * Correspondence: bolognap@montclair.edu; Tel.: +1-973-655-4112 \\ + These authors contributed equally to this work.
}

Received: 9 February 2019; Accepted: 22 April 2019; Published: 23 April 2019

\begin{abstract}
Stochastic events can have catastrophic effects on island populations through a series of genetic stressors from reduced population size. We investigated five populations of red mangrove (Rhizophora mangle) from St. John, USVI, an UNESCO Biosphere Reserve, which were impacted by Hurricane Hugo in 1989. Our goal was to determine diversity and to ascertain potential population bottlenecks two decades after the event. With the lowest observed heterozygosity, highest inbreeding coefficient, and evidence of a major bottleneck, our results demonstrated that the Great Lameshur mangroves, devastated by Hurricane Hugo, were the least diverse stand of trees. The other four populations from St. John manifested diversity reflecting the vegetation patterns of "fringing" mangrove or "developed forest" characteristics. The two fringing mangrove populations (Hurricane Hole and New Found Bay) evinced low observed heterozygosity and high inbreeding coefficients, while the fully forested sites showed higher heterozygosity and lower inbreeding frequencies. As such, fringing mangroves may be at greater risk to disturbance events and especially susceptible to sea level rise since they do not have room landward to expand. Our pair-wise population analysis indicated genetic similarity between the hurricane-damaged Great Lameshur and Coral Bay population, whose propagules were used in previous restoration attempts and is the geographically closest population. While the effective population size for Great Lameshur Bay places it in risk of genetic dysfunction, future rehabilitation of the site may be possible by the introduction of propagules from other regions of the island. However, recovery will ultimately be contingent upon hydrological connectivity and environmental improvements.
\end{abstract}

Keywords: genetic diversity; connectivity; UNESCO Biosphere Reserve; stochastic events

\section{Introduction}

Mangrove forests represent an important coastal habitat in tropical regions globally. They provide several critical ecosystem services including refuge for organisms, sediment stabilization, storm energy abatement, and carbon sequestration [1]. However, they are among the most threatened ecosystems due to anthropogenic destruction and climate change [2,3]. Specifically, mangroves are destroyed 
by humans to provide acreage for agriculture, housing, and aquaculture [4-6]. When these forests are destroyed, their ecosystem services are diminished and often cause detrimental ripple effects in adjacent communities [7]. Forest recovery after disturbance often takes decades due to the slow growth and re-formation of the physiological growth requirements of saplings after physical devastation of the environment $[1,8,9]$. Additionally, the reproductive capacity of the remaining trees may vary based on proximity to others and whether animal or wind pollination dominates, as well as the water-born dispersal phase of propagules. For red mangroves, they can exhibit flowering throughout the year, but generally have an annual peak in flowering and seed production. As they are viviparous, seedlings can develop prior to dispersal on the parent tree. This provides them an advantage for establishment in new areas and their long dispersal time-frame of more than a month with extended viability suggest that seedling can colonize distant regions, especially after disturbance events. Consequently, the length of recovery is often dependent upon propagule supply and success. Restoration efforts have accelerated the recovery of some forests [10]; however, continued anthropogenic stresses are leading to a net global loss of mangroves and the services they provide [4-6,11].

Consequently, conservation efforts are best applied proactively by protection of these forests, rather than reactional restoration of damaged systems. To that end, the United Nations Educational, Scientific, and Cultural Organization (UNESCO) Biosphere Reserves were initially founded in 1977 as internationally designated protected areas. There are over 600 Biosphere reserves in 117 countries (www.UNESCO.org). These reserves are designated regions that recognize the innate value of the communities and the ecosystem services they provide. In general, UNESCO Biosphere Reserves, like many protected areas, focus on community and species diversity, but not necessarily genetic diversity of the organisms within. However, as scientists begin to understand the response of individual species to environmental changes, the necessity of high levels of genetic diversity is becoming apparent $[12,13]$. Populations that demonstrate low levels of genetic diversity and connectivity are at greater risk of loss and potential extirpation because they lack the variation needed to survive environmental changes. Additionally, populations may lack the resiliency to survive and recover after a catastrophic event $[8,9]$, ultimately leading to community shifts and loss of ecosystem services.

While anthropogenic destruction of mangroves is still the dominant loss factor, natural disturbances also play a critical role in the health of these communities. Tropical storms can inflict significant damage to coastal ecosystems including mangroves, as well as associated communities like coral reefs and seagrass beds $[14,15]$. Seagrass beds have greater resiliency to disturbance given their growth rate compared to reefs and mangroves, and damaged seagrass systems may recover in a matter of years [16]. However, the recovery rate for mangrove forests may take decades. The U.S. Army Corps of Engineers suggests that mangrove habitats should be able to self-repair in 15-30 years after a stressor, if normal hydrology returns [17]. The mangrove forests of the United States Virgin Islands are dominated by three species including Rhizophora mangle (red mangrove), Avincennia germinans (black mangrove), and Laguncularia racemosa (white mangrove). Frequently, a zonation pattern occurs where red mangroves are closest to the shoreline and then transition into black mangrove forests landward. White mangroves, when encountered, are subsequently located further inland as they prefer less saline and drier soils.

Despite their protection through the UNESCO Biosphere Reserve, Rhizophora mangle (red mangrove) populations on St. John, United States Virgin Islands (USVI) have been devastated by anthropogenic and meteorological phenomena over the last half century, as have many other Caribbean mangrove populations. More than 15 hurricanes and frequent tropical storms have passed within 100 kilometers of St. John since 1900. The eye of Hurricane Hugo (category5), one of the most powerful storms in the Caribbean in the last century, passed over the island of St. Croix, $94 \mathrm{~km}$ west of St. John in 1989 [18-20]. This trajectory placed St. John in the North-East quadrant where winds and storm surge are accentuated and caused extensive damage. More recently, Hurricanes Irma (September 6, 2017) and Maria (September 20. 2017) have battered the region. 
Great Lameshur Bay and surrounding lands are part of the Virgin Islands National Park and the Coral Reef National Monument. The coastal mangrove forest was dominated by R. mangle historically, with a fringing presence of A. germinans and L. racemosa [21] Hurricane Hugo uprooted trees and destroyed most of the forest in Great Lameshur Bay, leaving behind only 34 surviving red mangrove trees $[20,21]$. Hugo also built up a sediment wall at the tidal creek mouth essentially eliminating tidal exchange [21]. This loss of tidal activity caused the system to experience substantial physiological stresses due to osmotic shifts and anoxia, but it also eliminated local recruitment of seedlings. Destruction to the other mangrove forests on the island due to Hurricane Hugo were not documented, but Reilly [18] described relatively minor losses in upland vegetation with minimal impacts on the leeward side of the island. In 1995, Hurricane Marilyn somewhat damaged the sediment wall, allowing some tidal flow to occur. Hurricane Lenny further improved tidal flow in 1999. A Lameshur Bay restoration attempt in 2003 planted $>1200$ mangrove seedlings, but survival was extremely low, $\sim 1 \%$ [21]. Water quality remained suboptimal due to the low tidal flow and the continued decomposition of organic matter, resulting in increased temperature, salinity, and reduced oxygen concentrations in the water [22]. A 2010 hurricane substantially re-opened the tidal channel and improved flow and water quality (Bologna, unpubl. data). These changes have resulted in active growth of the Great Lameshur forest and new seedlings have recruited into the open pan. While these observations are encouraging, continued island development will increase anthropogenic stresses, potentially leading to loss of these forests in the future. Additionally, large stochastic events like those witnessed in 2017 in the Caribbean are often agents of population declines leading to substantial changes in genetic diversity, genetic drift, inbreeding, effective population size, and bottlenecking. This investigation set out to address the following objectives, as no genetic data exist for $R$. mangle in this region: 1) Determine the genetic diversity of $R$. mangle from St. John, USVI; 2) assess genetic connectivity among populations; and 3 ) assess genetic bottlenecks and gene fixation among populations.

\section{Materials and Methods}

\subsection{Study Sites}

St. John lies on the edge of the Caribbean Plate and is part of the Greater and Lesser Antilles island chain. It has an underlying volcanic history, shaped by plate tectonics and regional uplift. It has relatively steep slopes with seasonal rainfall patterns of a rainy season and a dry season, which shape the vegetation patterns of the island [18]. Leaves from individual $R$. mangle trees were collected at five sites on the island of St. John in the U.S. Virgin Islands: Hurricane Hole (N: 18.351604, W: -64.692168), Great Lameshur Bay (N: 18.318655, W: -64.724214), Coral Bay (N: 18.346771, W: -64.771897), New Found Bay (N: 18.344922, W: -64.667811), and Leinster Bay (N: 18.362599, W: -64.722501) (Figure 1). These sites were chosen to reflect several regions of the island that remain minimally developed, compared to the anthropogenically impacted Western part of the island housing the primary city, Cruz Bay. Hurricane Hole, Great Lameshur Bay, and Leinster Bay exist within the limits of the US Virgin Islands National Park. The Coral Bay region is moderately developed, as it is outside the park boundaries, but the fringing mangrove forest remains intact. While New Found Bay is also outside the National Park, it is a remote eastern site accessible only by boat. These sites also differed in their construct, with Hurricane Hole, Coral Bay, and New Found Bay being characteristic of fringing mangroves; while Leinster and Great Lameshur Bays are characteristic of a coastal forest type mangrove. Samples from an outgroup population of $R$. mangle trees near Tampa Bay, Florida (N: 28.24103, W: -82.75483) were collected to statistically root $\mathrm{St}$. John populations and provide a geographic separation to assist in discriminating the primary research objectives of the project. This population was conserved/protected as part the Roberts Crown Wilderness Area in Florida and is subjected to stochastic weather events creating a site that is geographically isolated from St. John, but possessing similar environmental stresses and protection. 


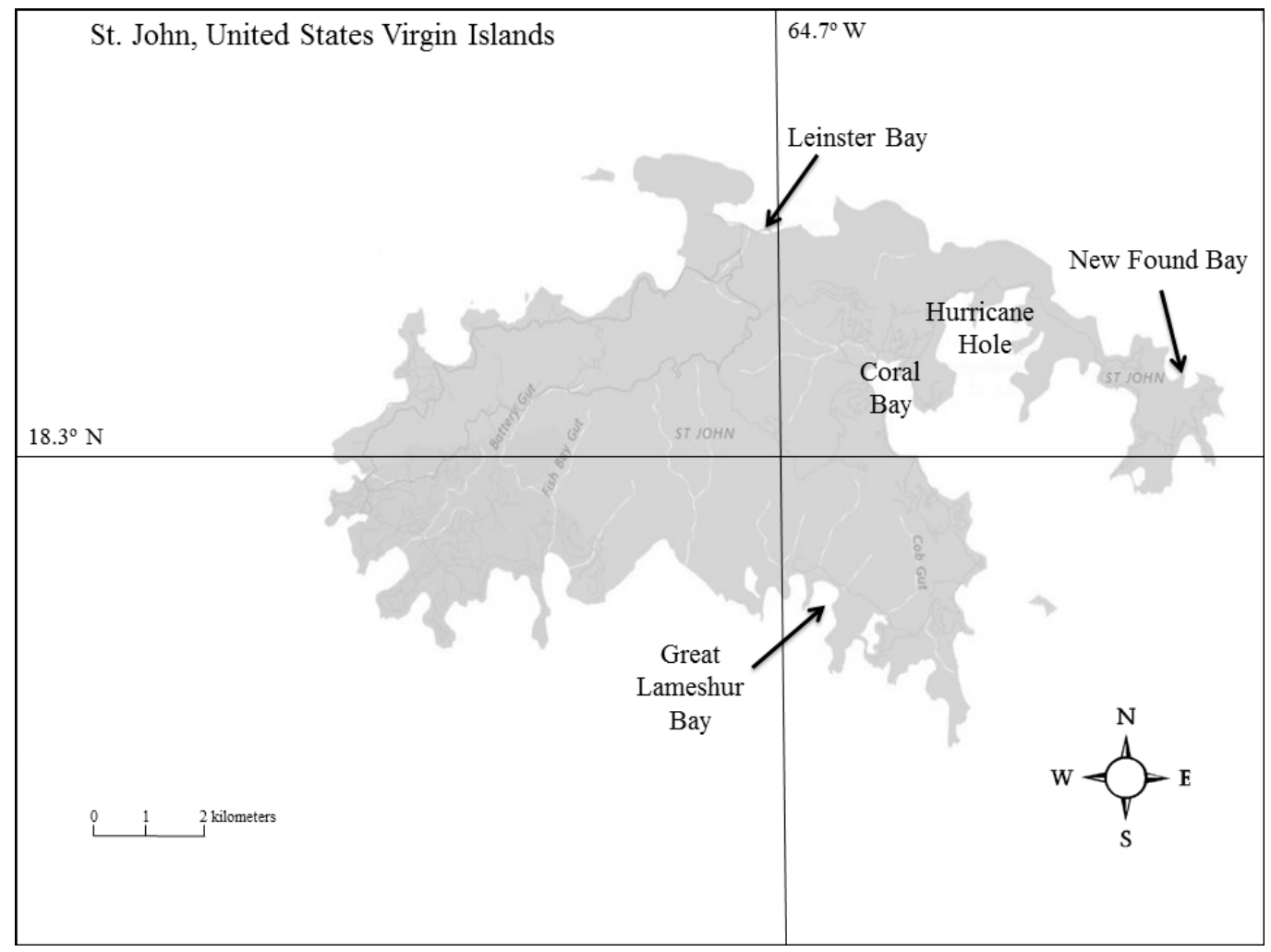

Figure 1. Geographic collection sites of the red mangrove populations studied.

\subsection{Plants Collection}

There was a physical limitation on the number of samples that could be recovered from locations, based on the size of the mangrove forests around the various bays and/or the accessibility of the trees, but we were able to minimally collect samples from at least 20 individuals in each population. All samples were taken from mature trees, with the exception of Great Lameshur, where two younger trees were among the trees sampled. Defining individual trees within the constructs of the forest was often difficult because of the lateral stem growth and overlapping, intertwined nature of these trees. As such, for all sites we endeavored to collect from apparent 'alternating' trees in the fringing mangrove sites to eliminate sampling multiple times from the same tree. While this limited the absolute number of samples we could collect at a site given the logistically challenging and time constraints associated with collection events, we feel that sufficient numbers of trees were sampled to assess the genetic diversity, connectivity, bottlenecks and gene fixation among the populations. Individual leaf samples were taken from trees, numerically labelled, preserved in DriRite (DriRite USA, Wintergarden, Florida), and transported to Montclair State University from all locations. Samples were then stored at room temperature until DNA extraction.

\subsection{DNA Extraction and Microsatellite Amplification}

Total DNA was extracted from 0.03-0.05 g of R. mangle dried leaf tissue, using the DNeasy DNA extraction kit according to the manufacturer's directions (Qiagen Corporation, Valencia, California). In the case of the Florida outgroup, all the 20 samples were extracted. From the remaining populations, random subsamples of less than 30 individuals were extracted from each location. DNA concentration was determined in the protocol outlined in Campanella et al. [23].

To amplify seven microsatellite loci from the extracted R. mangle DNA, PCR was utilized. Primers for these seven amplified loci were developed by Ribeiro et al. [24]: RmBra18, RmBra19, RmBra20, RmBra25, RmBra50, RmBra59, and RmBra64. Primers were synthesized and fluorescently labelled with FAM (Life Technologies Corp., Carlsbad, CA, USA). 
Seven loci were employed for this analysis for the pragmatic reasons of cost, time, and experience with previous research $[14,23,25]$. Additionally, Koskinen et al. [26] suggests that little benefit is gained when more than seven loci are utilized in a population genetic study that is non-evolutionary in nature.

The PCR reactions were carried out using the protocol of Campanella et al. [14] with modifications for the microsatellites employed. Specifically, the PCR program consisted of a 3 min denaturing step at $95^{\circ} \mathrm{C}$, followed by 40 cycles of the following times and temperatures: $45 \mathrm{~s}$ at $95^{\circ} \mathrm{C}, 45 \mathrm{~s}$ of annealing (RmBra18, $54{ }^{\circ} \mathrm{C}$; RmBra19. $54{ }^{\circ} \mathrm{C}$; RmBra20, $50{ }^{\circ} \mathrm{C}$; RmBra25, $50{ }^{\circ} \mathrm{C}$; RmBra50, $50{ }^{\circ} \mathrm{C}$; RmBra59, $54{ }^{\circ} \mathrm{C}$; and RmBra $64,53{ }^{\circ} \mathrm{C}$ ) and $60 \mathrm{~s}$ at $72{ }^{\circ} \mathrm{C}$. All amplified PCR products were then stored at $-20^{\circ} \mathrm{C}$ until later analysis.

\subsection{Microsatellite Allele Size Analysis}

Allele sizes of microsatellite PCR products were determined in the same manner as Campanella et al. [14]. The number of individuals in the R. mangle populations studied ranged from $\mathrm{N}=18$ to $\mathrm{N}=27$. Not all loci amplified for each individual DNA sample, presumably due to dropout (i.e., allele masking) at both alleles. To clarify, even though at least 20 individuals were employed for each locus analyzed, there were two instances with the Leinster Bay population where "N" was less than 20. The number of individuals analyzed $(\mathrm{N})$ was in line with recent publications where $R$. mangle was utilized for population genetics, including Kennedy et al. [27] $(\mathrm{N}=15-30)$ and Sandoval-Castro et al. [28] ( $\mathrm{N}=10-48)$.

\subsection{Statistical Analysis of Data}

Observed heterozygosity (Ho), expected heterozygosity (He), and the coefficients of inbreeding (FIS) were calculated with GenALEx v.6.5 under the codominant marker settings [29]. Negative FIS values indicate no evidence of inbreeding, while positive values show potential inbreeding. In addition, the Fst pair-wise population analysis was performed by GenALEx v.6.5. Microsat v.2.0 [30] was utilized to generate genetic distance matrices, based on the allele frequencies and employing 1000 bootstraps. The 1000 distance matrices generated were then analyzed by the Phylip v.3.6 subroutine Neighbor [31] for neighbor joining to produce neighbor-joined cladograms. The 1000 neighbor-joined trees were then collapsed down into a single consensus tree with the Phylip v.3.6 subroutine 'Consense' employing the majority rule (extended). The same process was employed with the generation of the genetic distance cladogram.

The program BOTTLENECK v.1.2.02 was used to estimate the likelihood of population bottlenecks [32], using the Two Phase Mutation (TPM), Infinite Allele (IAA), and Stepwise Mutation Hypothesis (SMM) models. The one-tailed Wilcoxon test was employed to examine heterozygosity excess only [33]. Allelic dropout rates for all loci were determined using Microdrop [34], employing the default settings for analysis.

The 2D Principal Coordinate Analysis (PCoA) on all the individual trees was performed employing Nei's genetic distance [35] in the GenALEx v.6.5 program. Program parameters were set to employ a triangular distance matrix. Visualization of the $2 \mathrm{D}$ analysis was then performed using R v.3.2.3 [36] in its Linux version and the ggplot2 graphics library [37].

\section{Results}

\subsection{Allelic Frequency Data and Diversity}

All the populations demonstrated some variability in allele number over all loci (mean $\mathrm{Na}=3.2-5.0$ ), but the New Found Bay trees exhibited the highest level of variability (mean $\mathrm{Na}=5.0$ ). The RmBra64 site is the most variable locus over all the populations with a mean $\mathrm{Na}=5.8$ (Table 1 ). The population that manifested the highest level of observed mean heterozygosity $(\mathrm{Ho}=0.540)$ was Leinster Bay and the lowest genetic diversity was found in Great Lameshur Bay $(\mathrm{Ho}=0.129)$. The observed heterozygosity of the other mangrove populations falls between these values (Table 1). 
Because the heterozygote frequencies observed in Hurricane Hole, New Found Bay, and Coral Bay were lower than predicted, all the populations were examined for allele dropout. None of the populations demonstrated serious signs of dropped alleles. The highest mean dropout frequency was the Florida population at 0.143 , but the Hurricane Hole population was also relatively high (0.115). We found an overall mean dropout rate of 0.091 among all populations and loci. When the coefficient of inbreeding was calculated, Leinster Bay had the lowest mean level of inbreeding, with the only mean negative coefficient of local inbreeding (Fis $=-0.083$ ) in the populations studied (Table 1). Great Lameshur had the highest evident level of inbreeding (mean Fis $=0.660$ ), while Coral Bay, Hurricane Hole, and New Found Bay all had lower mean inbreeding coefficients (Table 1), but only Leinster Bay displayed a mean negative Fis value. The Tampa Bay outgroup demonstrated an even higher mean frequency of inbreeding (Fis $=0.662$ ) and also had low genetic diversity (mean Ho $=0.214$ ).

Table 1. Genetic diversity in all of the populations of red mangrove studied. Designated markers reflect RmBra microsatellites with markers identified by their number and abbreviated RB. Na, number of alleles; $H_{0}$, observed heterozygotes; $H_{e}$, expected heterozygotes; $F_{I S}$, coefficient of local inbreeding; and $\mathrm{N}$, numbers of genets employed. $\mathrm{N} / \mathrm{C}=$ not calculated.

\begin{tabular}{|c|c|c|c|c|c|c|c|c|c|}
\hline Population & & RB 18 & RB 19 & RB 20 & RB 25 & RB 50 & RB 59 & RB 64 & Mean \\
\hline \multirow[t]{5}{*}{ Great Lameshur Bay } & $N$ & 25 & 25 & 25 & 25 & 25 & 25 & 25 & \\
\hline & $\mathrm{Na}$ & 3 & 5 & 5 & 3 & 2 & 2 & 3 & 3.286 \\
\hline & Ho & 0.080 & 0.040 & 0.040 & 0.280 & 0.200 & 0.280 & 0.000 & 0.129 \\
\hline & $\mathrm{He}$ & 0.486 & 0.318 & 0.558 & 0.498 & 0.241 & 0.449 & 0.150 & 0.386 \\
\hline & Fis & 0.835 & 0.874 & 0.928 & 0.438 & 0.169 & 0.376 & 1.000 & 0.660 \\
\hline \multirow[t]{5}{*}{ Coral Bay } & $N$ & 27 & 27 & 27 & 27 & 27 & 27 & 27 & \\
\hline & $\mathrm{Na}$ & 5 & 2 & 3 & 4 & 2 & 5 & 4 & 3.571 \\
\hline & Ho & 0.519 & 0.037 & 0.593 & 0.444 & 0.000 & 0.222 & 0.074 & 0.270 \\
\hline & $\mathrm{He}$ & 0.581 & 0.105 & 0.551 & 0.486 & 0.071 & 0.354 & 0.173 & 0.331 \\
\hline & Fis & 0.107 & 0.647 & -0.076 & 0.085 & 1.000 & 0.372 & 0.571 & 0.387 \\
\hline \multirow[t]{5}{*}{ Hurricane Hole } & $N$ & 22 & 22 & 22 & 22 & 22 & 22 & 22 & \\
\hline & $\mathrm{Na}$ & 4 & 5 & 3 & 3 & 2 & 2 & 6 & 3.571 \\
\hline & Ho & 0.045 & 0.136 & 0.227 & 0.227 & 0.227 & 0.000 & 0.045 & 0.131 \\
\hline & $\mathrm{He}$ & 0.170 & 0.286 & 0.280 & 0.526 & 0.449 & 0.087 & 0.454 & 0.322 \\
\hline & Fis & 0.733 & 0.523 & 0.188 & 0.568 & 0.494 & 1.000 & 0.900 & 0.630 \\
\hline \multirow[t]{5}{*}{ New Found Bay } & $N$ & 25 & 25 & 25 & 25 & 25 & 25 & 25 & \\
\hline & $\mathrm{Na}$ & 6 & 4 & 5 & 3 & 4 & 4 & 9 & 5.000 \\
\hline & Ho & 0.120 & 0.000 & 0.080 & 0.440 & 0.440 & 0.120 & 0.160 & 0.194 \\
\hline & $\mathrm{He}$ & 0.750 & 0.285 & 0.287 & 0.530 & 0.422 & 0.369 & 0.442 & 0.441 \\
\hline & Fis & 0.840 & 1.000 & 0.721 & 0.170 & -0.044 & 0.675 & 0.638 & 0.571 \\
\hline \multirow[t]{5}{*}{ Leinster Bay } & $N$ & 20 & 18 & 20 & 20 & 20 & 20 & 18 & \\
\hline & $\mathrm{Na}$ & 5 & 4 & 1 & 2 & 5 & 6 & 11 & 4.857 \\
\hline & Ho & 0.850 & 0.222 & 0.000 & 0.550 & 0.900 & 0.700 & 0.556 & 0.540 \\
\hline & $\mathrm{He}$ & 0.750 & 0.296 & 0.000 & 0.399 & 0.639 & 0.668 & 0.715 & 0.495 \\
\hline & Fis & -0.133 & 0.250 & $\mathrm{~N} / \mathrm{C}$ & -0.379 & -0.409 & -0.049 & 0.222 & -0.083 \\
\hline \multirow{5}{*}{ Tampa Bay, FL } & $N$ & 20 & 20 & 20 & 20 & 20 & 20 & 20 & \\
\hline & $\mathrm{Na}$ & 4 & 7 & 7 & 6 & 4 & 3 & 2 & 4.714 \\
\hline & Ho & 0.150 & 0.100 & 0.300 & 0.050 & 0.550 & 0.350 & 0.000 & 0.214 \\
\hline & $\mathrm{He}$ & 0.404 & 0.583 & 0.774 & 0.774 & 0.669 & 0.629 & 0.480 & 0.616 \\
\hline & Fis & 0.628 & 0.828 & 0.612 & 0.935 & 0.178 & 0.443 & 1.000 & 0.662 \\
\hline
\end{tabular}

\subsection{Genetic Distance and Bottlenecks}

The Edward's chord distance cladogram (Figure 2) was the most trustworthy phylogenetic prediction with all bootstrap values over $60 \%$ [38]. The tree morphology lends support to interactivity between the populations and also supports Florida as a geographic outgroup (Figure 2). The two adjacent St. John populations, Hurricane Hole and Coral Bay, clade together suggesting a level of genetic connection. Equally, the Leinster Bay and New Found Bay forests, in the North, end up in the same clade. Great Lameshur Bay ends up separated from all the other island populations with a high bootstrap value (707) supporting that tree topology, and further reinforcing Great Lameshur as being an impacted and isolated recovering population (Figure 2). 


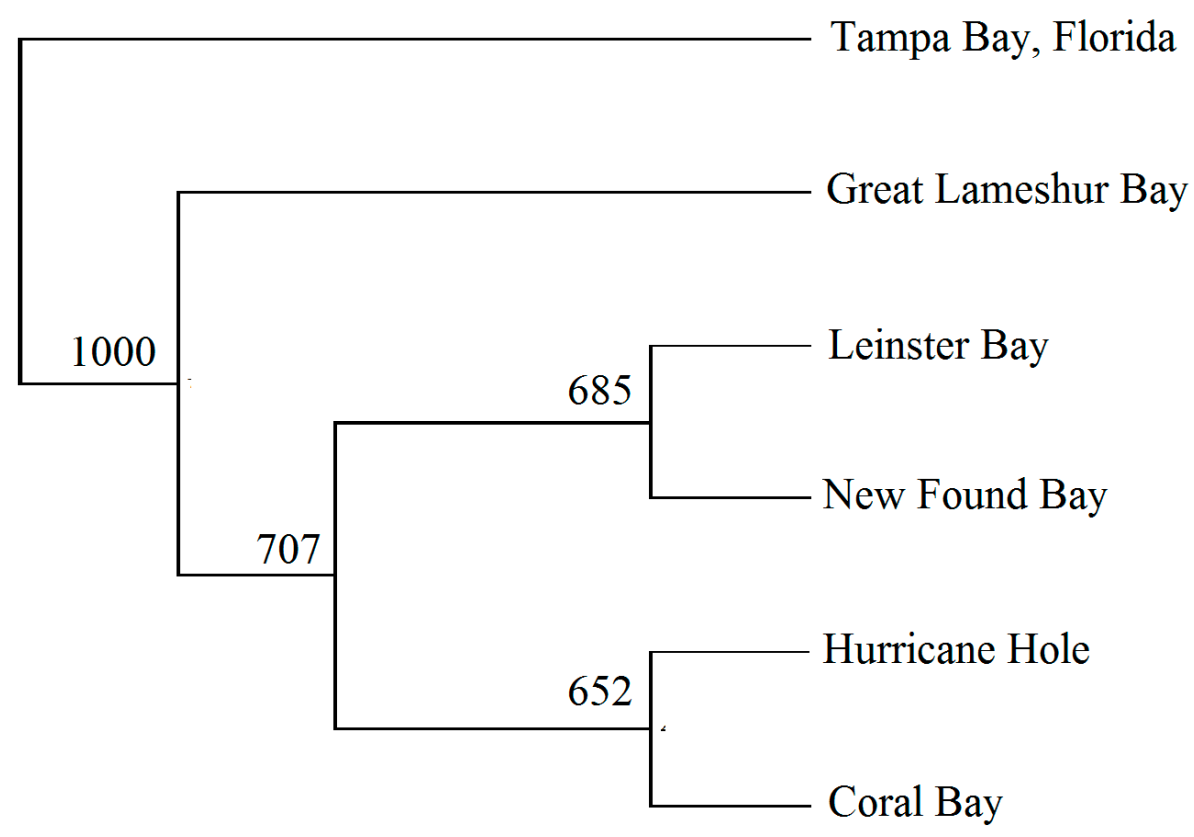

Figure 2. Rooted, neighbor-joining cladogram, illustrating the relationship among the five mangrove populations from the U.S. Virgin Islands. Reynold's genetic distance. The outgroup employed was an R. mangle population from Tampa Bay, Florida. 1000 bootstraps were performed.

The one-tailed Wilcoxon Bottleneck analysis was utilized following the assumptions of Luikart et al. [39], where $\alpha$-values indicating a heterozygote excess were interpreted as signs of a bottlenecked population, since this can result from the recruitment of new individuals after a population check. $\alpha$-values indicating a heterozygote deficiency were explained as robust or expanding populations. Using those criteria, the most bottlenecked populations were Great Lameshur and Tampa Bay, Florida (Table 2) under the Infinite Allele and Two Phase Models [40]. This result supports our hypothesis that after the severe dieback of R. mangle in Great Lameshur Bay 25 years ago, the population is less genetically diverse than its counterparts. Bottlenecks did not accompany the reduced levels of genetic diversity in Coral Bay, New Found Bay, and Hurricane Hole (Table 2). This result may be the best indication that the reduced diversity and increased inbreeding seen in these forests is not the result of a reduction of effective population size, but more likely represents imperfect assessment of established forests, without consideration of younger, non-reproducing trees.

Table 2. Bottlenecks analysis performed using three models of evolutionary change. The probability of population bottlenecks was determined using the one-tailed Wilcoxon test with the three models applied. Values supporting bottlenecks are in Bold.

\begin{tabular}{ccccc}
\hline Population & Stepwise Mutation & Infinite Allele & Two Phase Mutation & Mean \\
\hline Great Lameshur & 0.027 & $\mathbf{0 . 2 8 9}$ & $\mathbf{0 . 1 4 8}$ & $\mathbf{0 . 1 5 5}$ \\
Coral Bay & 0.007 & 0.019 & 0.007 & 0.011 \\
Hurricane Hole & 0.011 & 0.027 & 0.019 & 0.019 \\
New Found Bay & 0.007 & 0.019 & 0.019 & 0.015 \\
Leinster Bay & 0.039 & 0.078 & 0.039 & 0.052 \\
Tampa Bay, FL & 0.039 & $\mathbf{0 . 1 6 8}$ & $\mathbf{0 . 2 3 4}$ & $\mathbf{0 . 1 4 7}$ \\
\hline
\end{tabular}

\subsection{Fixation and Connectivity}

Differentiation between the populations was examined with pair-wise fixation index (Fst) values (Table 3). Florida was the most differentiated population (Fst $=0.104-0.194)$, as would be expected of a geographical outgroup. The island populations showed little differentiation among themselves with most Fst values well below 0.100 (Table 3). The Great Lameshur and Hurricane Hole groves showed 
the largest differentiation between any two island populations with 0.113 . This result would support the hypothesis that the protected Hurricane Hole and the exposed, damaged Great Lameshur share less genetic material than the other island populations.

Table 3. Mangrove pair-wise population $F_{S T}$ values (via allelic frequency).

\begin{tabular}{ccccccc}
\hline Populations & Great Lameshur & Coral Bay & Hurricane Hole & New Found Bay & Leinster Bay & Tampa Bay \\
\hline Great Lameshur & 0.000 & & & & & \\
Coral Bay & 0.033 & 0.000 & & & & \\
Hurricane Hole & 0.113 & 0.078 & 0.000 & & & \\
New Found Bay & 0.044 & 0.044 & 0.046 & 0.000 & 0.000 & \\
Leinster Bay & 0.072 & 0.095 & 0.112 & 0.049 & 0.119 & 0.000 \\
Tampa Bay, FL & 0.104 & 0.155 & 0.194 & 0.129 & 0.19 \\
\hline
\end{tabular}

The Hurricane Hole and Leinster Bay populations are almost as differentiated (Fst $=0.112$ ) as Hurricane Hole and Great Lameshur. Both Hurricane Hole and Leinster have been physically protected from hurricanes by their geography and neither show bottlenecks. It is likely that the sources of the differentiation between the two forests are geographic in nature. Leinster and Hurricane Hole are two of the more distant populations by the water route, and furthermore, currents around the island do not allow for easy communication of propagules between the two locations.

An additional connectivity study was performed using a principal coordinate analysis (Figure 3). The variation of all seven microsatellite loci in all 139 trees investigated was compared to clarify how the individual trees are related to one another. The Tampa Bay population is clearly a geographic outgroup to the island populations. The individual Tampa Bay trees are spread out and mostly separated along the Coordinate 2 axis (Figure 3). There is some crossover of individuals from Great Lameshur Bay, Leinster Bay, and New Found Bay, but the bulk of the St. John trees stay separated on one edge of the Tampa Bay "orbit".

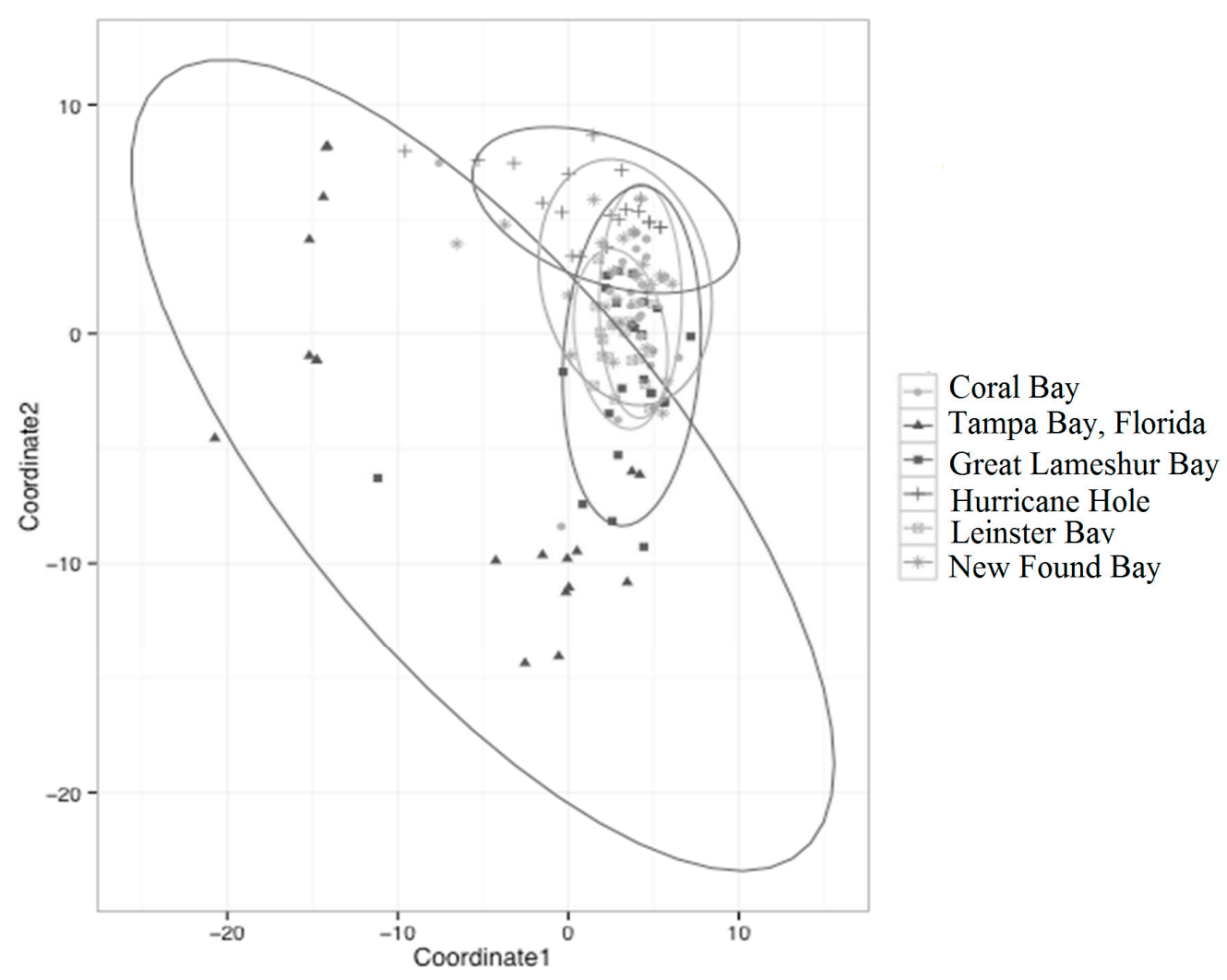

Figure 3. Principal coordinate analysis of the 139 mangrove trees examined in this study. 2D PCoA employing genetic distances derived from microsatellite genotypes. 


\section{Discussion}

Mangrove forests are essential habitat for fish and invertebrates and contribute to fish biomass on nearby reefs [7]. Additionally, they represent a substantial carbon sink through production of organic matter and burial within the anoxic sediments contributing to substantial carbon sequestrations [41,42]. However, mangrove forests have seen significant global declines in the last half century from ever increasing human impacts on these communities as sites for aquaculture, housing and coastal development, as well as harvests for wood [4]. As global losses continue from direct human activities, changes in climate conditions may add indirect pressures on these communities through sea level rise and increases in frequency and intensity of tropical storms [43,44].

One troubling factor from these dramatic global declines is the potential for severe genetic degradation among impacted mangrove populations. While large, intact forests may show strong resilience to multiple climate stressors [9,45], fringing and isolated populations may exhibit low genetic diversity, population bottlenecks, and inbreeding [12]. Consequently, evaluating the genetic diversity of these populations is critical to assessing their resilience under the current climate changes and can allow us to develop sound restoration goals to improve genetic diversity.

When we examined the genetic diversity among the St. John populations, they did not differ greatly from other red mangrove populations in the Caribbean or Central/North America. Takayama et al. [46] found that four Mexican mangrove forests exhibited a range of Ho values from 0.13 to 0.42, with a central Florida forest having a Ho $=0.35$. The same study reported the most diverse Mexican population with no evidence of inbreeding (Fis $=-0.23$ ) and the Florida population evincing high levels of inbreeding with a Fis $=0.35$. Sandoval-Castro et al. [28] also found comparable diversity in mangroves along the Caribbean coast of Mexico, where the mean Ho for the five populations studied was $0.26 \pm 0.02$. More recently, Kennedy et al. [27] examined the genetic diversity of $R$. mangle in the islands of the Caribbean and Florida. This report revealed that among eight populations scattered over the region, none had a Fis value below zero, and all displayed various levels of inbreeding, especially populations from Puerto Rico (Fis $=0.26$ ) and the Florida Everglades (Fis $=0.23$ ). However, a more comprehensive assessment of genetic diversity, resulting from range expansion in Florida, by Kennedy et al. [47], indicated higher levels of genetic diversity $(\mathrm{Ho}=0.2-0.48)$ in these younger populations due to natural dispersal of propagules.

While inbreeding and low genetic diversity pose significant genetic deficiencies in populations, evolutionary bottlenecks are bellwethers of populations ill-adapted to survive environmental or climactic shifts [48]. Our results show that the Great Lameshur and Tampa Bay populations are genetically bottlenecked (Table 2). Both of these systems have shown destruction by hurricanes, including Hugo (1989) in St. John and Andrew (1992), which destroyed mangrove forests throughout southwest and central Florida [49]. Additionally, a series of cold snaps across the Florida peninsula in the early 1990s [50], may have curtailed mangrove recruitment in the area. These events resulted in population checks and could be responsible for in the lack of genetic diversity, high inbreeding, and bottlenecks observed in the Great Lameshur and Tampa Bay populations. Interestingly, both of these systems have had restoration efforts to accelerate re-growth [21,51,52], but development of fully recovered forests may take decades, and it is possible that insufficient time has occurred to provide functional trajectories of resilient populations. Additionally, many restoration efforts have focused on establishment of individuals, irrespective of genetic diversity. While this may support short-term establishment goals, without a robust genetic diversity among planted individuals, restored sites may fail in the long-term under changing environmental conditions. Consequently, restoration efforts should assess the regional plant genetic diversity and potentially employ propagules from numerous populations to improve resiliency under future climatic changes $[53,54]$.

When we evaluated the regional relatedness among populations, one unexpected result was the similarity in Fst values between the New Found Bay population and all others on St. John (Table 3), despite the larger geographic distance. Two potential, but opposing, mechanisms may explain this. New Found Bay could be a source of propagules or pollen for the other four populations 
or it could be a sink. Seedling recruitment from more distant populations is a realistic possibility. Red mangroves have wind-pollinated flowers [55] that produce a fruit which germinates and begins growing while attached to the parent. Propagules then release and can float in a viable state in the water for up to a year [1]. While this scenario could produce propagules for broad distribution, New Found Bay is a fringing mangrove community with open exposure to the ocean on the Eastern side of St. John. Propagules produced certainly could travel both North to Leinster Bay and South to the other three populations, but prevailing wind patterns suggest that there would be a greater possibility that this population could be a distant source of pollen. Both scenarios could explain the relatedness, but analysis of propagules from all systems would be necessary to discern between these two possibilities. The other pair-wise sites with high connectedness are Coral Bay with both Hurricane Hole and Great Lameshur (Fst 0.078 and 0.033, respectively). The close geographic distance between Coral Bay and Hurricane Hole indicates that both pollen and propagules could easily be shared. The similarity with Great Lameshur, however, is most likely due to the fact that Coral Bay was a source of propagules used in restoration efforts [20]. The cladogram supports specific connectivity between the two geographically "northern" populations (the Leinster Bay and New Found Bay clade) and the two "southern" populations (the Hurricane Hole and Coral Bay clade), but Great Lameshur manifests more genetic distance from all the other island populations (Figure 2). Edward's chord model [38] makes no biologic assumptions and is generated by a geometric view of the distances between multi-dimensional points on a hypersphere. This result supports Takezaki and Nei [56], who found that the chord model, using microsatellite data, produced some of the most reliable trees, when put to the test against other common distance models.

The principal coordinate analysis provides further evidence for the connectivity among the St. John populations. The $2 \mathrm{D}$ analysis shows the Tampa Bay population is clearly a geographic outgroup with its own "constellation" (Figure 3). Although a few individual trees in the island populations are outliers with Tampa Bay, most are quite homogenous compared to the other island populations. In short, $\sim 79 \%$ of the trees from the island populations cover a small area/volume of the PCoAs, suggesting overall homogeneity and broadly perhaps a meta-population (Figure 3). One question that still remains unanswered is why it has taken Great Lameshur more than 25 years to re-establish red mangrove trees. The generation times of red mangroves has been estimated to be 10 to 40 years [57]. Based on those assessments, Great Lameshur could have developed an additional one to two generations of $R$. mangle since Hurricane Hugo, but our results do not support this.

So what may have happened to inhibit regrowth? The best explanation is that Hurricane Hugo altered topography, hydrologic conditions, salinity, and/or soil characteristics in the system making mangrove recovery and regrowth inhospitable. Krauss et al. [58] reviewed the limitations to recovery and development of mangrove forests by environmental stressors and identified all of these, as well as photoinhibition, as substantial limiting factors. Kontos and Bologna [59] and Bologna [22] document hypoxia within the mangrove channel in Great Lameshur due to the flow restrictions caused by Hurricane Hugo. Low dissolved oxygen has been shown to reduce mangrove seedling growth [60] and sedimentary features (e.g., $\mathrm{H}_{2} \mathrm{~S}$, Eh) negatively affect survival of seedlings leading to mortality exceeding recruitment [61]. Additionally, reliance on propagules from other populations may limit recovery due to their buoyancy and poor transport mechanisms [62]. Since the destruction of the forest in 1989, the slow recovery may simply be the result of lack of seedling survival due to altered environmental conditions. Proffitt et al. [63] found reduced reproduction in R. mangle populations in Florida following Hurricane Charlie, while Harris et al. [64] documented that reduced tidal flushing significantly reduced seedling abundance and plant productivity. The Great Lameshur mangrove forest was subjected to these stressors and the lack of recovery is supported by these findings. This is very troubling, because the low genetic diversity and population bottlenecking suggest that Great Lameshur does not have an effective population size for long-term survival, while the other populations are less in danger. Small populations are generally threatened to become extinct based on genetic drift, 
stochastic inheritance, and environmental variation. Even a less powerful hurricane than Hugo coming close to St. John, may exert significant stress on an already vulnerable population.

One way to address both the functional and genetic problems encountered during the loss of mangrove trees is through active restoration [10]. In this way, population growth can be accelerated by the use of seedlings leading to elevated genetic diversity and minimizing recruitment limitations. Frequently, restoration and recovery are dependent upon a favorable change in environmental parameters [58]. Previous restoration efforts have been impeded for years at similar sites that were previously hospitable to mangrove growth $[1,18,20,21]$. In 2010, Hurricanes Otto (category 1) and Earl (category 4) helped dramatically to open the tidal channel in the devastated forest of Great Lameshur, thereby increasing exchange with the ocean and improving water quality (Bologna unpublished data). This return of tidal flow is critical for mangrove seedlings to thrive, as they lack the physiological tolerance that adult trees exhibit $[1,21]$. This is likely why early restorations were unsuccessful and recovery has not taken place at the pace expected, given the undeveloped and pristine nature of this area. For the long-term success of this forest, more aggressive restoration activities may be required. However, without an improvement to generalized water quality through elevated tidal exchange, the prognosis is limited [65]. Large-scale restoration efforts have seen success, but success is not a guarantee if environmental stressors are not controlled and active management is not employed [66]. Additionally, geomorphology and hydrology are critical elements for recovery and restoration of mangroves $[65,67]$ and this appears to be a critical factor in the health of the Great Lameshur Bay forest. The impacts of recent hurricanes in the Caribbean have yet to be fully evaluated, but the potential exists that Hurricanes Irma and Maria could have damaged additional mangrove populations [68] and reset the resilience clock for mangrove recovery in St. John.

Author Contributions: Conceptualization, P.A.X.B., J.J.C. and D.J.R.; Methodology, J.J.C., D.J.R. and J.V.S.; Validation, P.A.X.B., J.J.C. and J.V.S.; Formal analysis, J.J.C. and J.V.S.; Investigation, D.J.R., Z.A.F. and M.L.; Data curation, Z.A.F., J.J.C. and J.V.S.; Writing-original draft preparation, J.J.C. and P.A.X.B.; Writing-review and editing, P.A.X.B., J.J.C. and J.V.S.; Visualization, J.J.C. and J.V.S.; Supervision, P.A.X.B. and J.J.C.; Project administration, P.A.X.B. and J.J.C.; Funding acquisition, J.J.C.

Funding: This research work was supported in part by a Margaret and Herman Sokol Fellow Award, \#07A [JJC].

Acknowledgments: We would like to thank the staff and volunteers of the Virgin Islands Environmental Resource Station for providing logistical support for the field collections in St. John and the numerous students who help with field activities. We would also like to thank Tina Bologna for collecting the mangrove samples from Florida and Lisa Campanella for her help in editing this manuscript.

Conflicts of Interest: The authors declare no conflict of interest.

\section{References}

1. Hogarth, P.J. The Biology of Mangroves and Seagrasses, 3rd ed.; Biology of habitats; Oxford University Press: Oxford, UK, 2015.

2. Field, C.D. Impact of Expected Climate Change on Mangroves. Hydrobiologia 1995, 295, 75-81. [CrossRef]

3. Gilman, E.L.; Ellison, J.; Duke, N.C.; Field, C. Threats to Mangroves from Climate Change and Adaptation Options: A Review. Aquat. Bot. 2008, 89, 237-250. [CrossRef]

4. Valiela, I.; Bowen, J.L.; York, J.K. Mangrove Forests: One of the World's Threatened Major Tropical Environments. BioScience 2001, 51, 807. [CrossRef]

5. Lovelock, C.E.; Cahoon, D.R.; Friess, D.A.; Guntenspergen, G.R.; Krauss, K.W.; Reef, R.; Rogers, K.; Saunders, M.L.; Sidik, F.; Swales, A.; et al. The Vulnerability of Indo-Pacific Mangrove Forests to Sea-Level Rise. Nature 2015, 526, 559-563. [CrossRef]

6. Hamilton, S.E.; Casey, D. Creation of a High Spatio-Temporal Resolution Global Database of Continuous Mangrove Forest Cover for the 21st Century (CGMFC-21): CGMFC-21. Glob. Ecol. Biogeogr. 2016, 25, 729-738. [CrossRef]

7. Mumby, P.J.; Edwards, A.J.; Ernesto Arias-González, J.; Lindeman, K.C.; Blackwell, P.G.; Gall, A.; Gorczynska, M.I.; Harborne, A.R.; Pescod, C.L.; Renken, H.; et al. Mangroves Enhance the Biomass of Coral Reef Fish Communities in the Caribbean. Nature 2004, 427, 533-536. [CrossRef] 
8. Alongi, D.M. Present State and Future of the World's Mangrove Forests. Environ. Conserv. 2002, 29, 331-349. [CrossRef]

9. Alongi, D.M. Mangrove Forests: Resilience, Protection from Tsunamis, and Responses to Global Climate Change. Est. Coastal Shelf Sci. 2008, 76, 1-13. [CrossRef]

10. Lewis, R.R. Ecological Engineering for Successful Management and Restoration of Mangrove Forests. Ecol. Eng. 2005, 24, 403-418. [CrossRef]

11. Ellison, A.M. Mangrove Restoration: Do We Know Enough? Restor. Ecol. 2000, 8, 219-229. [CrossRef]

12. Bozzano, M.; Jalonen, R.; Thomas, E.; Boshier, D.; Gallo, L.; Cavers, S.; Bordács, S.; Smith, P.; Loo, J. (Eds.) Genetic Considerations in Ecosystem Restoration Using Native Tree Species. State of the World's Forest Genetic Resources - Thematic Study; FAO and Biodiversity International: Rome, Italy, 2014.

13. Thomas, E.; Jalonen, R.; Loo, J.; Boshier, D.; Gallo, L.; Cavers, S.; Bordács, S.; Smith, P.; Bozzano, M. Genetic Considerations in Ecosystem Restoration Using Native Tree Species. For. Ecol. Manag. 2014, 333, 66-75. [CrossRef]

14. Campanella, J.J.; Bologna, P.A.X.; Carvalho, M.; Smalley, J.V.; Elakhrass, M.; Meredith, R.W.; Zaben, N. Clonal Diversity and Connectedness of Turtle Grass (Thalassia testudinum) Populations in a UNESCO Biosphere Reserve. Aquat. Bot. 2015, 123, 76-82. [CrossRef]

15. Puotinen, M.; Maynard, J.A.; Beeden, R.; Radford, B.; Williams, G.J. A robust Operational Model for Predicting Where Tropical Cyclone Waves Damage Coral Reefs. Sci. Rep. 2016, 6, 26009. [CrossRef]

16. Williams, S. Disturbance and Recovery of a Deep-Water Caribbean Seagrass Bed. Mar. Ecol. Prog. Ser. 1988, 42, 63-71. [CrossRef]

17. Lewis, R.R.; Streever, B. Restoration of Mangrove Habitat, WRP Technical Notes Collection (ER $T N-W R P-V N-R S-3.2) ;$ U.S. Army Engineer Research and Development Center: Vicksburg, MS, USA, 2000.

18. Reilly, A.E. The Effects of Hurricane Hugo in Three Tropical Forests in the U.S. Virgin Islands. Biotropica 1991, 23, 414. [CrossRef]

19. Rogers, C.S.; McLain, L.N.; Tobias, C.R. Effects of Hurricane Hugo (1989) on a coral reef in St. John, USVI. Mar. Ecol. Prog. Ser. 1991, 78, 189-199. [CrossRef]

20. Cohn, J.P. Paradise in peril. Americas 2003, 55, 6-13.

21. Devine, B.; Blondeau, J. Restoration of Wetlands at Lameshur Bay. Mapping, Assessment, Planting and Monitoring Report; Center for Marine and Environmental Sciences: St. Thomas, VI, USA, 2004; p. 32.

22. Bologna, P.A.X. Mangrove Loss Leads to Fish Hyperutilization of Seagrass Beds in a UNESCO Biosphere Reserve. J. Fish Biol. 2014, 84, 1620-1625. [CrossRef]

23. Campanella, J.J.; Bologna, P.A.; Smalley, J.V.; Rosenzweig, E.B.; Smith, S.M. Population Structure of Zostera marina (Eelgrass) on the Western Atlantic Coast Is Characterized by Poor Connectivity and Inbreeding. J. Hered. 2010, 101, 61-70. [CrossRef]

24. Ribeiro, D.O.; Vinson, C.C.; Nascimento, D.S.S.; Mehlig, U.; Menezes, M.P.M.; Sampaio, I.; Silva, M.B. Isolation of Microsatellite Markers for the Red Mangrove, Rhizophora mangle (Rhizophoraceae). Appl. Plant Sci. 2013, 1, 1300003. [CrossRef]

25. Campanella, J.J.; Bologna, P.A.X.; Smalley, J.V.; Avila, D.N.; Lee, K.N.; Areche, E.C.; Slavin, L.J. An Analysis of the Population Genetics of Restored Zostera marina Plantings in Barnegat Bay, New Jersey. Pop. Ecol. 2013, 55, 121-133. [CrossRef]

26. Koskinen, M.T.; Hirvonen, H.; Landry, P.-A.; Primmer, C.R. The Benefits of Increasing the Number of Microsatellites Utilized in Genetic Population Studies: An Empirical Perspective: Increasing the Number of Microsatellites in Genetic Population Studies. Hereditas 2004, 141, 61-67. [CrossRef]

27. Kennedy, J.P.; Pil, M.W.; Proffitt, C.E.; Boeger, W.A.; Stanford, A.M.; Devlin, D.J. Postglacial Expansion Pathways of Red Mangrove, Rhizophora Mangle, in the Caribbean Basin and Florida. Am. J. Bot. 2016, 103, 260-276. [CrossRef]

28. Sandoval-Castro, E.; Dodd, R.S.; Riosmena-Rodríguez, R.; Enríquez-Paredes, L.M.; Tovilla-Hernández, C.; López-Vivas, J.M.; Aguilar-May, B.; Muñiz-Salazar, R. Post-Glacial Expansion and Population Genetic Divergence of Mangrove Species Avicennia germinans (L.) Stearn and Rhizophora mangle L. along the Mexican Coast. PLoS ONE 2014, 9, e93358. [CrossRef]

29. Peakall, R.; Smouse, P.E. GenAlEx 6.5: Genetic Analysis in Excel. Population Genetic Software for Teaching and Research-an Update. Bioinformatics 2012, 28, 2537-2539. [CrossRef] 
30. Minch, E.; Ruiz-Linares, A.; Goldstein, D.; Feldman, M.; Cavalli-Sforza, L.L. MICROSAT: A Computer Program for Calculating Various Statistics on Microsatellite Allele Data, VERSION 1.5d; Stanford University: Palo Alto, CA, USA, 1997.

31. Baum, B.R. PHYLIP: Phylogeny Inference Package. Version 3.2. Joel Felsenstein. Q. Rev. Biol. 1989, 64, 539-541. [CrossRef]

32. Piry, S.; Luikart, G.; Cornuet, J.-M. Computer Note. BOTTLENECK: A Computer Program for Detecting Recent Reductions in the Effective Size Using Allele Frequency Data. J. Hered. 1999, 90, 502-503. [CrossRef]

33. Cornuet, J.M.; Luikart, G. Description and power analysis of two tests for detecting recent population bottlenecks from allele frequency data. Genetics 1996, 144, 2001-2014.

34. Wang, C.; Schroeder, K.B.; Rosenberg, N.A. A Maximum-Likelihood Method to Correct for Allelic Dropout in Microsatellite Data with No Replicate Genotypes. Genetics 2012, 192, 651-669. [CrossRef]

35. Nei, M. Genetic Distance between Populations. Am. Nat. 1972, 106, 283-292. [CrossRef]

36. R Core Team. R: A Language and Environment for Statistical Computing; R Foundation for Statistical Computing: Vienna, Austria, 2013.

37. Wilkinson, L. Ggplot2: Elegant Graphics for Data Analysis by WICKHAM, H. Biometrics 2011, 67, 678-679. [CrossRef]

38. Cavalli-Sforza, L.L.; Edwards, A.W.F. Phylogenetic Analysis: Models and Estimation Procedures. Evolution 1967, 21, 550. [CrossRef] [PubMed]

39. Luikart, G. Distortion of Allele Frequency Distributions Provides a Test for Recent Population Bottlenecks. J. Hered. 1998, 89, 238-247. [CrossRef] [PubMed]

40. Di Rienzo, A.; Peterson, A.C.; Garza, J.C.; Valdes, A.M.; Slatkin, M.; Freimer, N.B. Mutational Processes of Simple-Sequence Repeat Loci in Human Populations. Proc. Nat. Acad. Sci. 1994, 91, 3166-3170. [CrossRef] [PubMed]

41. Bouillon, S.; Borges, A.V.; Castañeda-Moya, E.; Diele, K.; Dittmar, T.; Duke, N.C.; Kristensen, E.; Lee, S.Y.; Marchand, C.; Middelburg, J.J.; et al. Mangrove Production and Carbon Sinks: A Revision of Global Budget Estimates: GLOBAL MANGROVE CARBON BUDGETS. Glob. Biogeochem. Cycles 2008, 22. [CrossRef]

42. Siikamaki, J.; Sanchirico, J.N.; Jardine, S.L. Global Economic Potential for Reducing Carbon Dioxide Emissions from Mangrove Loss. Proc. Nat. Acad. Sci. 2012, 109, 14369-14374. [CrossRef] [PubMed]

43. Webster, P.J. Changes in Tropical Cyclone Number, Duration, and Intensity in a Warming Environment. Science 2005, 309, 1844-1846. [CrossRef]

44. Knutson, T.R.; McBride, J.L.; Chan, J.; Emanuel, K.; Holland, G.; Landsea, C.; Held, I.; Kossin, J.P.; Srivastava, A.K.; Sugi, M. Tropical Cyclones and Climate Change. Nat. Geosci. 2010, 3, 157-163. [CrossRef]

45. Jennerjahn, T.C.; Gilman, E.; Krauss, K.W.; Lacerda, L.D.; Nordhaus, I.; Wolanski, E. Mangrove Ecosystems under Climate Change. In Mangrove Ecosystems: A Global Biogeographic Perspective: Structure, Function, and Services; Victor, H.R.-M., Lee, S.Y., Erik, K., Robert, R.T.C., Eds.; Springer International Publishing: Cham, Switzerland, 2017; pp. 211-244. [CrossRef]

46. Takayama, K.; Tamura, M.; Tateishi, Y.; Webb, E.L.; Kajita, T. Strong Genetic Structure over the American Continents and Transoceanic Dispersal in the Mangrove Genus Rhizophora (Rhizophoraceae) Revealed by Broad-Scale Nuclear and Chloroplast DNA Analysis. Am. J. Bot. 2013, 100, 1191-1201. [CrossRef]

47. Kennedy, J.P.; Garavelli, L.; Truelove, N.K.; Devlin, D.J.; Box, S.J.; Chérubin, L.M.; Feller, I.C. Contrasting Genetic Effects of Red Mangrove (Rhizophora Mangle L.) Range Expansion along West and East Florida. J. Biogeogr. 2017, 44, 335-347. [CrossRef]

48. Colautti, R.I.; Alexander, J.M.; Dlugosch, K.M.; Keller, S.R.; Sultan, S.E. Invasions and Extinctions through the Looking Glass of Evolutionary Ecology. Philos. Trans. R Soc. Lond. B Biol. Sci. 2017, 372, 20160031. [CrossRef]

49. Smith, T.J.; Robblee, M.B.; Wanless, H.R.; Doyle, T.W. Mangroves, Hurricanes, and Lightning Strikes. BioScience 1994, 44, 256-262. [CrossRef]

50. Hebert, P.J. Freezes and hurricanes in Florida. Nat. Weath. Dig. 1993, 18, 1-11.

51. Lewis, R.R. Time Zero Plus 60 Months Report for the Cross Bayou Mangrove Restoration Site, Pinellas County, Florida; Prepared for the Cross Bayou Project Review Group, Tampa, Florida; Lewis Environmental Services: Salt Springs, Marion County, FL, USA, 2004.

52. Osland, M.J.; Spivak, A.C.; Nestlerode, J.A.; Lessmann, J.M.; Almario, A.E.; Heitmuller, P.T.; Russell, M.J.; Krauss, K.W.; Alvarez, F.; Dantin, D.D.; et al. Ecosystem Development After Mangrove Wetland Creation: Plant-Soil Change Across a 20-Year Chronosequence. Ecosystems 2012, 15, 848-866. [CrossRef] 
53. Engelhardt, K.A.M.; Lloyd, M.W.; Neel, M.C. Effects of Genetic Diversity on Conservation and Restoration Potential at Individual, Population, and Regional Scales. Biolog. Conserv. 2014, 179, 6-16. [CrossRef]

54. Kettenring, K.M.; Mercer, K.L.; Reinhardt Adams, C.; Hines, J. EDITOR'S CHOICE: Application of Genetic Diversity-Ecosystem Function Research to Ecological Restoration. J. Appl. Ecol. 2014, 51, 339-348. [CrossRef]

55. Nadia, T.L.; Machado, I.C. Wind Pollination and Propagule Formation in Rhizophora Mangle L. (Rhizophoraceae): Resource or Pollination Limitation? Anais da Academia Brasileira de Ciências 2014, 86, 229-238. [CrossRef]

56. Takezaki, N.; Nei, M. Genetic distances and reconstruction of phylogenetic trees from microsatellite DNA. Genetics 1996, 144, 389-399.

57. Polidoro, B.A.; Carpenter, K.E.; Collins, L.; Duke, N.C.; Ellison, A.M.; Ellison, J.C.; Farnsworth, E.J.; Fernando, E.S.; Kathiresan, K.; Koedam, N.E.; et al. The Loss of Species: Mangrove Extinction Risk and Geographic Areas of Global Concern. PLoS ONE 2010, 5, e10095. [CrossRef]

58. Krauss, K.W.; Lovelock, C.E.; McKee, K.L.; López-Hoffman, L.; Ewe, S.M.L.; Sousa, W.P. Environmental Drivers in Mangrove Establishment and Early Development: A Review. Aquat. Bot. 2008, 89, 105-127. [CrossRef]

59. Kontos, C.C.; Bologna, P.A.X. Assessment of fish and decapod distributions between mangrove and seagrass habitats in St. John, USVI. Bull. N. J. Acad. Sci. 2008, 53, 7-11.

60. McKee, K.L. Growth and Physiological Responses of Neotropical Mangrove Seedlings to Root Zone Hypoxia. Tree Physiol. 1996, 16, 883-889. [CrossRef]

61. Padilla, C.; Fortes, M.D.; Duarte, C.M.; Terrados, J.; Kamp-Nielsen, L. Recruitment, Mortality and Growth of Mangrove (Rhizophora Sp.) Seedlings in Ulugan Bay, Palawan, Philippines. Trees 2004, 18. [CrossRef]

62. Imbert, D.; Rousteau, A.; Scherrer, P. Ecology of Mangrove Growth and Recovery in the Lesser Antilles: State of Knowledge and Basis for Restoration Projects. Restor. Ecol. 2000, 8, 230-236. [CrossRef]

63. Edward Proffitt, C.; Milbrandt, E.C.; Travis, S.E. Red Mangrove (Rhizophora mangle) Reproduction and Seedling Colonization after Hurricane Charley: Comparisons of Charlotte Harbor and Tampa Bay. Est. Coasts 2006, 29, 972-978. [CrossRef]

64. Harris, R.J.; Milbrandt, E.C.; Everham, E.M.; Bovard, B.D. The Effects of Reduced Tidal Flushing on Mangrove Structure and Function Across a Disturbance Gradient. Est. Coasts 2010, 33, 1176-1185. [CrossRef]

65. Van Loon, A.F.; Te Brake, B.; Van Huijgevoort, M.H.J.; Dijksma, R. Hydrological Classification, a Practical Tool for Mangrove Restoration. PLoS ONE 2016, 11, e0150302. [CrossRef]

66. Kodikara, K.A.S.; Mukherjee, N.; Jayatissa, L.P.; Dahdouh-Guebas, F.; Koedam, N. Have Mangrove Restoration Projects Worked? An in-Depth Study in Sri Lanka: Evaluation of Mangrove Restoration in Sri Lanka. Restor. Ecol. 2017, 25, 705-716. [CrossRef]

67. Balke, T.; Friess, D.A. Geomorphic Knowledge for Mangrove Restoration: A Pan-Tropical Categorization: Geomorphic Knowledge for Mangrove Restoration. Earth Surf. Proc. Landforms 2016, 41, 231-239. [CrossRef]

68. Daley, B.; Coldren, S. Rapid Health Assessment of Coral Bay Mangrove Forests; Post Irma and Maria Conditions; Geographic Consulting: Christiansted, VI, USA, 2018; p. 14.

(C) 2019 by the authors. Licensee MDPI, Basel, Switzerland. This article is an open access article distributed under the terms and conditions of the Creative Commons Attribution (CC BY) license (http://creativecommons.org/licenses/by/4.0/). 